\title{
Martina Olivero
}

University of Paris 1 Panthéon-Sorbonne

\section{Tragic Narrative Strategies in Contemporary American Cinema. Eastwood-Penn-Grey (1995-2001)}

\section{The Role of Tragedy in the Excess of Visuality}

Tragedies were performed for the first time in ancient Greece between the sixth and fifth century BC, but it was only a century later that Aristotle studied in the Poetics the tragic structures, basically transforming tragedy into a narrative genre. Nevertheless, we don't want to compare contemporary American mainstream films to ancient Greek tragedies here; neither will we consider contemporary transpositions of ancient tragedies. In other words, our aim is not so much to describe the formal structures of a tragedy, as they were firstly studied and recognised by Aristotle, but to see through them in order to create a contemporary aesthetics of tragic narrative solutions.

Actually, this thesis was first suggested by Bernard Sichère in a lecture given at the French National Library in 2012 on the interpretation of the Antigone drama by French psychoanalyst Jacques Lacan. Sichère identifies a main tendency in contemporary art and movies in the impossible need to go beyond the representable. However, art has always been concerned by an unrepresentable, unbearable "thing" that Lacan calls either La Chose or Das Ding (referring to Heidegger). But this Thing, which stands at the very heart of reality, is also what Slavoj Zižek calls The Real. In an article which appeared in the journal Savoirs et clinique (39), the Slovenian philosopher asks the reader to think about the famous Kinder chocolate egg. As a matter of fact, in this case, people are not really interested in eating the chocolate, since what they care most about is the surprise it contains. This void, filled by the surprise at the centre of the Kinder egg, is then compared to the inner part of our desire, which, according to Lacan, 
always escapes to us, never being totally satisfied. In Žižek's perspective, no goods will ever fill our desire. This is why, in a psychoanalytic view, sometimes in art, and especially in contemporary artistic tendency, there is a strong will to deeply explore the infinite human desire and give this void a face. Sichère considers the crisis of contemporary art in general, and I will add: of some currents of contemporary cinema as well, is due to the paradoxical resolution of representing this unrepresentable, which finally entails a failure of the device itself. In other words, the camera does not gain in power while showing the last stage of the unnameable, visually depicted by a perpetration, an over-exposition and an omnipresence of blood, human hair, organs, and wounds in a systematic and repetitive way. Now, if we consider the definition given by Aristotle we could say, with Jean Ungaro who refers to American solo-hero action movies, that the spectator's participation at the hero's sufferance implies making this sufferance visible by many processes: howls, cries, groans, open wounds, blood. Or by the use of different weapons, sharp objects and instruments of torture: chains, sticks, iron bars, fire extinguishers, chainsaws, hammers, screwdrivers, kitchen knives, razors. Sufferance must be seen to be felt by the spectator, whence blood that spurts full screen, flesh in tatters, traces of the blows on bodies, corpses piled up. The body must ostensibly wear the stigmas (87).

Otherwise, we can find this very same tendency in a large number of works from figurative and plastic art, starting from Body Art to many other contemporary performers from Marina Abramovich to Chris Burden, from Gina Pane to Petr Pavlensky, from Herman Nitsch to ORLAN. Now, let us explain all the evil and sufferance displayed in some contemporary artworks and movies just in the name of a cathartic deliverance from fear and terror ("through pity (eleos) and fear (phobos) it [the tragedy] achieves a purgation (katharsis) of emotions (phatemata) corresponding to these", Aristotle, 1449b 27-28)?. Can we justify the representation of horror as a major way to exorcise the animal, ancestral, pre-thinking, our savage passions? In an attempt not only to approach it, to be scared and inspired by it but at the same time to represent it, to give the Thing a face, many movies become a manifestation of open bodies, organs, rapes, incest and many other terrible things we cannot even imagine. In our attempt to give an interpretation of this large phenomenon, we should consider the contemporary tyranny of images. We could indeed read this common cinematographic tendency as a consequence of what Guy Debord (1931-1994) calls the spectacularisation of society. In his famous thesis presented in 1967, French philosopher Debord describes the modern consumerist and mass society with an absolute dominion of the spectacle. The spectacle is not just a collection of images, but rather it represents social relationships that are persistently mediated by images. In a consumerist society, social life is not anymore about living, but about having; the spectacle uses the image to convey what people need and must have. Moreover, social life moves forward, leaving a state of "having" and proceeding into a state of "appearing"; namely the appearance of the image. We could thus suppose that this aestheticisation of the world that comes with the 
celebration of war and violence (Debord, 2013), largely presented in contemporary cinema, is strictly connected with the spectacularisation of evil and tyranny of the visible (very close to totalitarian aesthetics). Debord defines it with the concept of Spectacle. The society of the spectacle defines a society where images have taken the place of human relationships, where they are associated with political power and capitalistic intentions and where they are not recording history anymore, they have taken power over history itself. Our suggestion here is that a free, repetitive and omnipresent aestheticisation of violence and suffering is a consequence of the massive development of images which has led to an excess of visuality.

On the other hand, if we focus for a moment on the ancient tragedy, which Aristotle was referring to, it is clear that it was not thought to expose us to what we have called the unnameable, nor did it bear it directly. The stratified complexity of a tragic play, which includes recitation, dance, music, costumes, architecture, and scenography, was specifically built to keep this deadly zone at a distance, to save spectators from it. Never in a tragic scene, that showed the most terrible, fierce and merciless stories, did we see Antigone hanging herself or Oedipus extricating his own eyes or Medea stabbing her two little kids. On the one hand, tragedy is not conceived to plunge us in front of the unnameable. While on the other, tragic narratives enable us to take distance from this core that Lacan, in Seminar VII, indifferently names (the Real of) the Thing or Das Ding in German (55-85, 121-137 and following). Through a careful analysis of the text of Sophocles' play, Lacan succeeds in defining a possible pattern of the tragic structure. In order to do that, he indeed uses the image of a central void, which is progressively enveloped by different layers: the first one represented by the Beautiful, the second one by the Good. At the very centre of the tragedy, there is something terrible and irremediable, to which the tragic action seeks to come closer, without representing it directly. Anything terrible that happens to the tragic protagonist is only suggested through the complex apparatus of the tragic device (text, recitation, music, dance, scenography, and costumes). For example, and again according to Lacan, it is only thanks to Antigone's dazzling beauty that the spectators can withstand such a pitiless end. In this case, the play uses all the possible aesthetic devices to make the tragic excess bearable.

We will now analyse three different cinematographic examples of media narratives that use tragic devices. These films are presented here in relation to at least one major tragic, both narrative and aesthetic, solution, by isolating single elements that belong to classic tragic forms. We argue that they should be considered as samples of contemporary tragedies.

\section{The Unrepresentable, Unnameable Thing}

The Pledge: Requiem for the Detective Novel (Das Versprechen: Requiem auf den Kriminalroman, 1958) was originally a novel by Friedrich Dürrenmatt, based on 


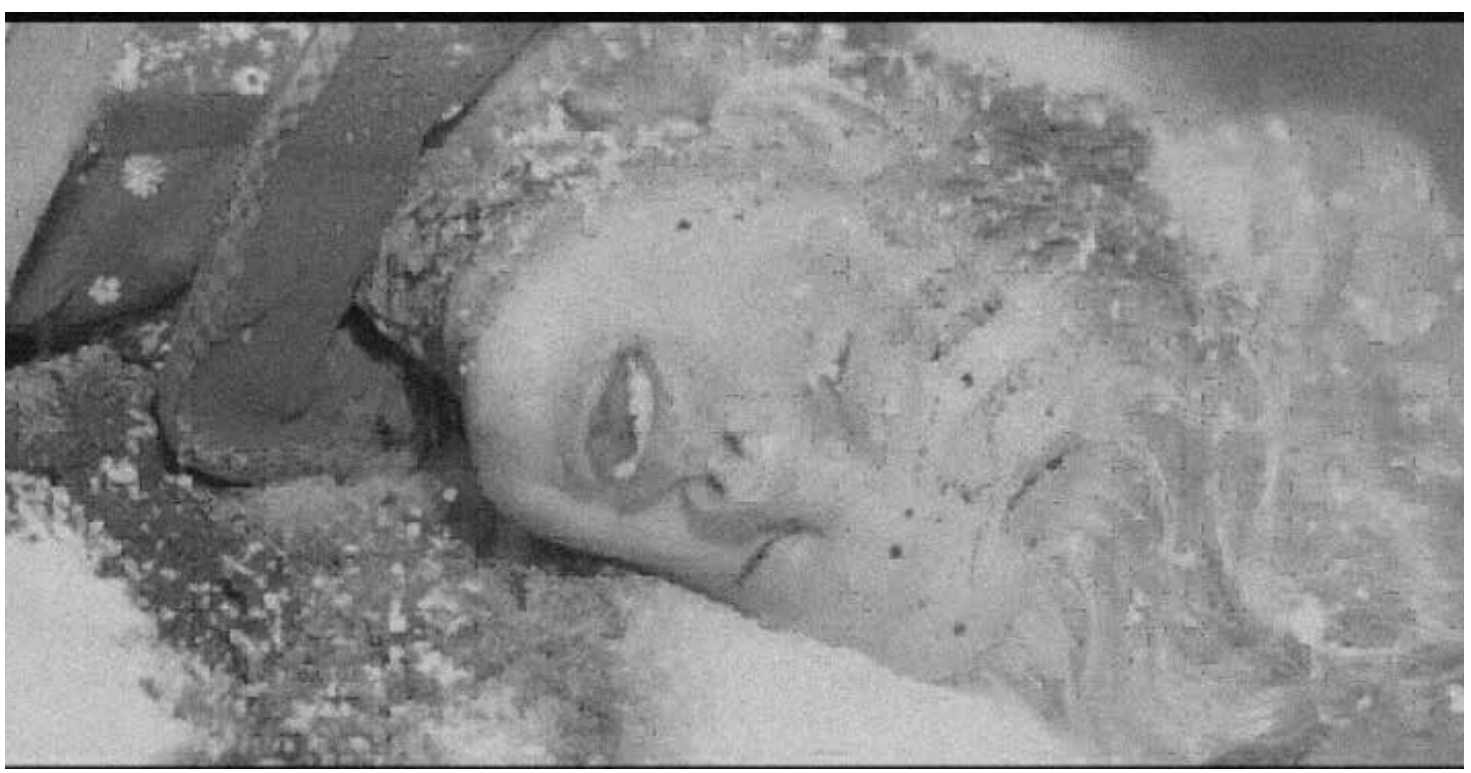

Image 1. The Pledge (Sean Penn, USA, 2011).

the script of It Happened in Broad Daylight written together with Vajda and Hans Jacobi (Es geschah am hellichten Tag, Switzerland, West Germany, Spain, 1958), whose feature was directed by Hungarian Ladislao Vajda. Dürrenmatt, who was not happy to see the detective proven successful at the end of the story, decided to write a new novel starting from the previous film script. Das Versprechen differs from Es geschah am hellichten Tag by having the detective fail to identify the killer in the end because of the murderer's death in a car accident. This failure ultimately leaves the detective a broken and witless old man. Moreover, I also found an Italian version of the film titled The promise (released in 1978 and directed by Italian director Alberto Negrin) realised for Italian national television. The movie includes Dürrenmatt's tragic end and the detective Matthai becoming crazy by continuing to search for the murderer, accidentally killed in a car accident. Nevertheless, the cinematographic version that interests us for its tragic structure is the one directed by American filmmaker Sean Penn in 2011 and based on the screenplay by the Pole Jerzy Kromolowski and his wife Mary Olsen-Kromolowski,, with music by Hans Zimmer. The action starts (as most of Penn's films do) with a preview of his conclusion, showing a dirty, disturbed old man, whose image is superimposed with another one displaying birds flying in a blue sky, a recurrent theme all over the narration. Next to the beautiful and peaceful long shots of snowy Nevada landscapes, the most terrible thing occurs: the slaughtered raped body of a little girl is found (Image 1). However, the image of the child's corpse is not shown but for a very few seconds and only suggested by a nearly imperceptible sequence of rapid flashes that still imprint irremediably on the spectator's mind. In other words, they provoke that shock effect that Walter Benjamin was arguing about in The work of art in the age of its technological reproducibility (127-133), without violating the formal rules of the representation, which is exactly how the impossible, unbearable thing at the very heart of tragedy works. 
Immediately after that retired detective Jerry Black (Jack Nicholson) is asked to promise on a crucifix to find the little girl's rapist and murderer. From that moment, without being aware of it, he has sentenced himself to death. That promise would become for a fatal pledge for Black. It is only at the end, however, that he appears as a real tragic hero: not only is no redemption accorded to him, but we finally come to know that promise has become his madness. Like Oedipus, who by killing a passerby unwillingly transformed himself into a parricidal, detective Black is himself the author of his own final perdition. Tragically, he cannot know that his investigation is actually right and that the suspected murderer was actually coming to the appointment he had made with him but was fortuitously killed in a car accident on his way there. In the impossibility to find him, Jerry becomes his own obsessing pledge and after having lost his family as a result of that, he is finally condemned to lose his reason, too, and spends the rest of his life as a crazy and completely lonely lost man.

There is another typical tragic element that is used in the film: blindness. Traditionally, there are two types of tragic blindness. The first one is prophetical and typically afflicts soothsayers, like Tiresias. Its conviction is in some way transformed into a gift that assures a clear, mantic vision of the future. But besides that, there is a damned version of blindness. This is the kind of disability that affects Oedipus at the end of his life, and which is intended as a sort of selfredemption and purgation for the crimes he committed, unconsciously. Now, because the superimposed scenes of detective Black staring into space with his eyes closed occur twice, both at the beginning and at the end of the film, we have reason to consider that it is an important clue to reading the narration. Black is not physically blind, but still, we could say that because of his eyes that are kept closed during this prophetic sequence, shown at the very beginning of the feature, his is a mental blindness (Image 2). In that case, it would be a sign

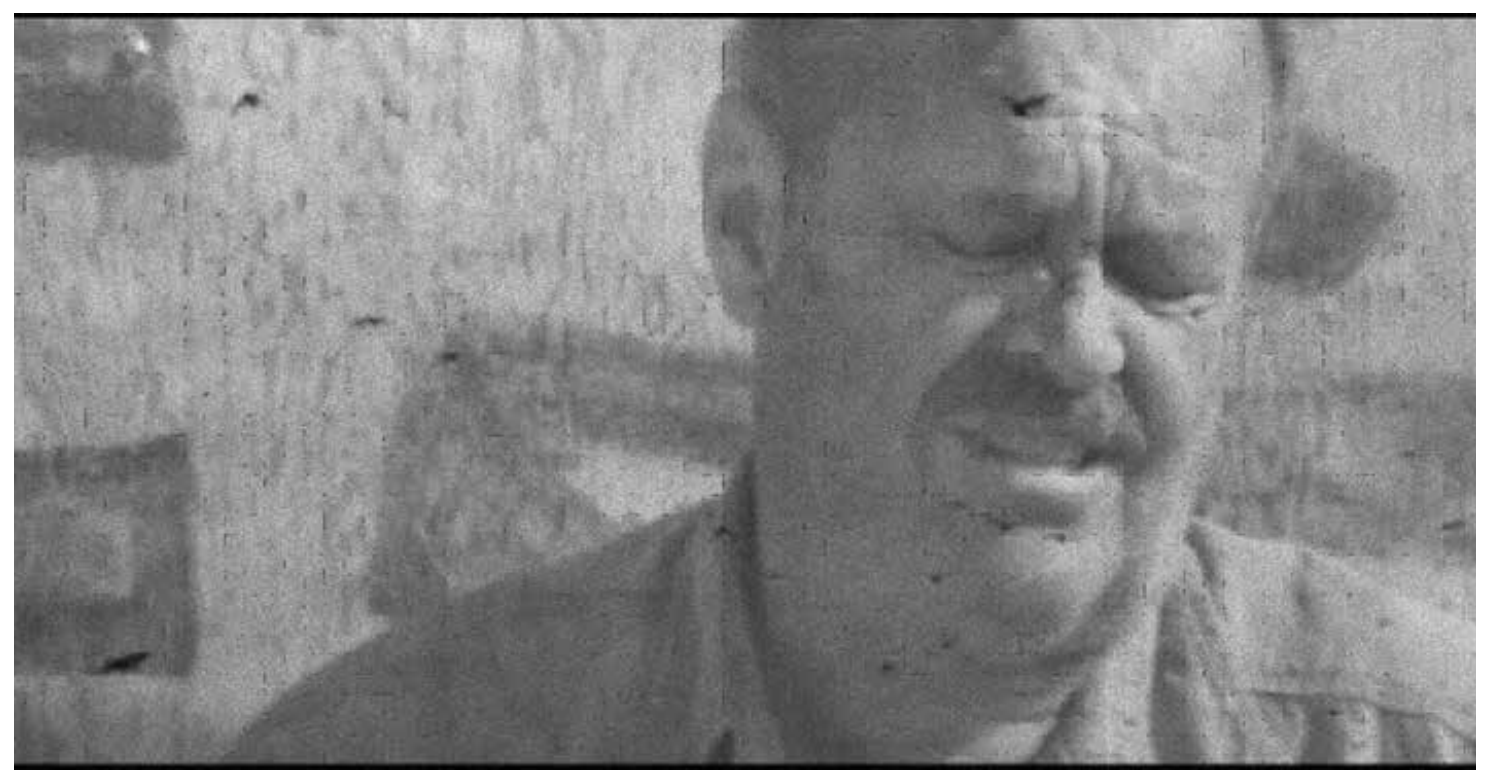

Image 2. Jack Nicholson in The Pledge (Sean Penn, USA, 2011). Initial sequence 
of his tragic insanity: apparently, he is depicted as a lone crazy man but he is actually the only one who has seen the truth. In that sense, he stands between Tiresias, because of his real knowledge, and Oedipus, because its damnation is irremediable.

\section{The disruption of traditional ethical values}

The second element which I would like to draw your attention to is the political dimension of the tragic narrative. From the Aristotelian definition of tragedy as the achievement of purgation (katharsis) through pity (eleos) and fear (phobos), we can say that the tragic action had a positive effect on the citizen-spectatorship and thus it contributed to a better public life in the polis. Yet, when Aristotle gave the first theorisation on tragic narrative structures in the fourth century BC, in many respects he was already far from the tragic man of the sixth century $\mathrm{BC}$, the time when the tradition of the tragic myth in Greece was born. By expressing itself as an original literary genre, it is a new thought, a new man, a new vision of the world (Weltanschauung), in other words, a new tragic consciousness that sees the light (Vernant-Naquet 1088). For this reason, the social and political context in which the tragedy was born is not marginal. The tragedy is not just a form of art but also a social institution. Vernant suggests that the relationship between tragedy and the social context in which it has been developed may be thought of in terms of a double antinomy (Vernant-Naquet 1089). On the one hand, the chorus represents the political community, who speaks not to celebrate or to worship, but to reflect, question and problematise the tragic subject under the philosophical and political thought. Yet, the language used by the chorus is that of the traditional lyric poetry, to which Simonides, Bacchylides, and Pindar belong. In this sense, we should say that the illustrious lyric poets of the preceding epoch prepare the birth of tragedy. Then, besides the chorus, the protagonists of the tragic action are part of the great heroic and religious traditions. Despite that, they express themselves in prose, as if they want to make themselves immortal and contemporary to the audience at the same time. Thus, in one person, the tension between the mythological past and the present of the polis is crystallised. This is why Vernant and Naquet suggest that the real question about tragedy does not concern its origins, but the social and psychological elements that have made it possible for this literary genre to transform and revolutionise not only the literature, but also the theatrical, philosophical and artistic fields up to the present day (1081). The tragic phenomenon is indeed characterised by the permanence of two kinds of awareness, a new political consciousness and a traditional mythical presence, human justice and sacred norms. So for the first time, tragedy challenges traditional ethical and religious values in the name of a new legal and political universe. Indeed, it started to develop when the concept of human responsibility for actions began to spread and when man undertook to interpret himself as an autonomous agent before the natural and sacral elements of the universe. This is translated into tragic characters' constantly questioning 
their own actions. However, according to Nietzsche in The birth of tragedy from the spirit of music, tragic inspiration interrupted precisely when this query had become more systematic, namely with the institutionalisation of the Platonic Academy and then the Aristotelian philosophy.

Little Odessa, written and directed by James Grey (USA, 1995), awarded with a Silver Lion at the $51^{\text {st }}$ Venice International Film Festival, takes place in Brighton Beach, a prevalent Russian speaking community in Brooklyn (NY), which, because of its intense Soviet migration, starting from the '70s, has been renamed Little Russia or Little Odessa. The movie, a mafia tale taking place in New York City, has for a protagonist a Russian-Jewish family whose elder son is irremediably engaged in the Brooklyn's underworld. The entire film can be read as a contemporary Dostoevsky narrative: a harsh, pitiless, tragic drama, where, again, no redemption is accorded to the main characters. The story is built on the succession of a crime and its punishment but in a context where neither common ethics nor the public legal system is effective. Mafia, indeed, acts silently behind and beside the institutional system. It operates as an invisible organisation with its own social divisions, rules, and traditions. Little Odessa, as the Antigone by Sophocles, shows a world where two parallel ethical orders coexist. In the ancient tragedy, the traditional established laws that belong to Creon, who represents state power, fail in front of blood ties, in the name of which Antigone faces the death penalty in order to bury her brother Polynices, against the king's edict. In the movie, the public justice is completely ineffective to restore legality. The protagonist Joshua (Tim Roth), a violent murderer, can be considered as an anti-Oedipian figure. Instead of committing parricide by mistake, he deliberately decides to kill his own father, and only then he fails in shooting him (Image 3). There is, however, a contradiction between the purpose of his action and its modality: his gesture, as in a typical mafia context, is

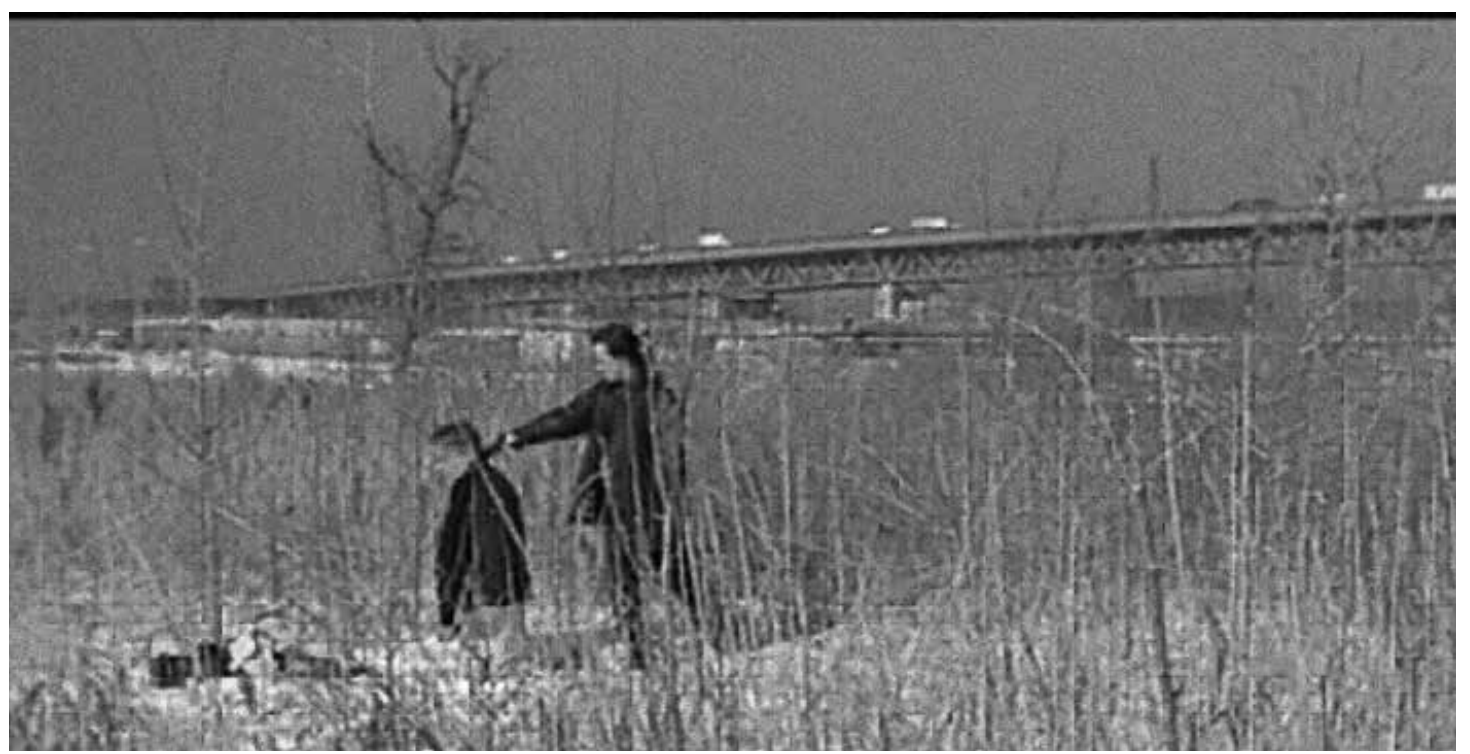

Image 3. The abortive parricide in Little Odessa (James Grey, USA, 1995). 
schizophrenic as it intends to prevent violence by using violence. The tenderness for his beloved little brother Reuben (Edward Furlong) cannot be undertaken without embracing the most brutal means. Thus, the love for a brother turns into the failed killing of his own father, the loyalty to his fellows leads to the death of other "enemies" companions, and so on.

Furthermore, throughout the film music plays a fundamental role. Its beauty is stunning, severe and solemn and gives the perfect balance to the harshness and roughness of the scenes. In the end, a powerful Russian choral song is played as if a tragic orchestra was singing off-screen, the camera starts recording a cold, lifeless and snowy suburb in Brooklyn and then frames Joshua's empty look who has fatally lost those dearest to him. His mother has died of brain cancer, his girlfriend Alla and little brother Reuben perished because of intransigent mafia revenge and a series of fatal mistakes. The effect of the three elements (music, landscape, and foreground on the protagonist's hopeless gaze) convey to create an oppressive, unbearable and grim narrative which perfectly represents the entire film.

\section{Ancestral, Sacred, Primitive Forces}

The third element I would like to discuss is represented by the tragedy's savage dimension. According to Montani, the tragic phenomenon is veritably the advent of the truth, in Greek $\alpha \lambda \eta \dot{\theta} \theta \varepsilon{ }^{\alpha}$ (IX-XVIII). Despite the nobility of its verses, this performative art always retains a libidinal, wild aspect, with Nietzsche "orgiastic" thanks to its musical spirit (chapter XXI 147-154). This thesis can also be corroborated by the etymology of the Greek root $\tau \rho \alpha \gamma$, that refers to the name $\tau \rho \alpha$ ó $\gamma$ s, goat. Indeed, it seems that the Eschyleian tragedies were preceded by performances that took place on the occasion of the Dionysian festivals. This confirms that the great tragic playwrights, Aeschylus, Sophocles, and Euripides, only formalised some less noble content, in other words, traditional popular songs. Again, the etymology of tragedy ( $\tau \rho \alpha \gamma \omega \delta i ́ \alpha)$ seems

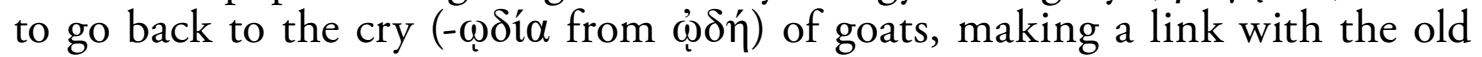
satirical and calumnious representations played during the Bacchanalian feasts, where a goat was the sacrificial victim or the prize awarded to the best actor. Furthermore, it is thought that originally actors wore masks of goats, or even, according to the meaning of the verb $\tau \rho \alpha \gamma i \zeta \varepsilon v$, they performed imitating the animal's bleating. For all these reasons, it is not inconsiderate to foresee a certain connection between a tragic event and the meaning of "truth". It has also been conceived by some philosophers that the truth always deals with an obscure, wild and informal nature. For instance, Heidegger considers $\alpha-\lambda \eta \dot{\eta} \theta \varepsilon 1 \alpha$ (truth) as the perennial movement of veil-unveiling a dark and unutterable background, a relationship between the fierce Earth and the human World and according to Nietzsche it is the irreducible dialectic between the formal Apollonian and the orgiastic Dionysian element. Thus, tragedy inhabits, dialectically, the 
space-time between its popular origin and its sublimatory, ecstatic and almost mystical effect.

Tragedy absorbs the musical orgiastic enthusiasm to its highest degree, so that suddenly, among the Greeks as well as us, it brings music to its perfection. But it immediately adds to it the tragic myth (and hero) which, like a mighty titan, takes on its shoulders the whole weight of the Dionysian world and relieves us of it, while on the other hand - always through the myth but this time in the person of the hero - it knows how to deliver us from the incoercible desire that drives us towards this existence, reminding us of the thought of another being and of a higher form of pleasure, which the hero presses throughout the battle he leads, but to which he is, in fact, prepared by his own ruin and not by his victories. (Nietzsche 148).

In this passage from The birth of tragedy from the spirit of music, there are two elements that must be retained. The first one is, of course, the essential musical nature of the tragic event. Concerning the other one, Nietzsche names here the figure of the tragic hero, who is not without importance. It is on him that the resolution of the narrative plot is based. As Nietzsche clearly explained, the tragic hero's first feature consists of rejecting the blind instinct of survival and of denying life as the supreme value. An attitude which is perfectly embodied by the heroine Antigone, for example. Hence, according to Lacan, the greatest tragic value is Desire and the ability to pursue it at all costs. Considering "life" or "survival" everything that concerns personal interests, well-being, and daily pleasures, the tragic hero, though not indifferent to them, does not take them into account when it comes to making his own choices. Let us think about Oedipus, who extricates his own eyes, or Medea, who barbarously kills her children, or Antigone, who hangs herself. And if this was not enough, all of them are desperately aware while doing it. The choice of the hero puts before us the disturbing, intolerable and unbearable presence of an excess, which by nature does not belong to the order of what we ethically consider as "rational". The tragic excess escapes any justification, it refuses any explanation. The excess belongs to pure carnality, it is quite an ancestral, primitive, fierce instinct. Indeed, men are never alone on stage but always accompanied by a presence. This presence in the ancient tragedy is played by the Gods whose intervention never has a secondary role. Later Camus will identify them with the tragic sacred element. For him, tragedy seems to be a phenomenon only reserved for fixed periods in history.

Midnight in the garden of good and evil (USA, 1997) is an American crime drama film directed and produced by Clint Eastwood. It is based on the 1994 homonym novel by John Berendt, which became the NY Times best seller of all time and was then a finalist for the Pulitzer Prize in 1995. Settled in the American deep south, Savannah (Georgia) and Beaufort (South Carolina), the movie is based on true events that happened in the 1980s but that were then 
rearranged. The title alludes to the voodoo notion of "midnight", the period between the time for good magic (11 pm to midnight) and the time for evil magic (midnight to $1 \mathrm{am}$ ), while "the garden of good and evil" refers principally to the cemetery in Beaufort, South Carolina, where Dr. Buzzard, the husband of Minerva, the voodoo priestess who figures in the story, is buried. The cover of the book, later used for the film posters, is a sculpture titled The bird girl, made by artist Sylvia Shaw Judson (1936). Four statues were actually obtained from the original mold and the most famous one was placed in Bonaventure cemetery (Savannah, GE). Then, a Savannah photographer, Jack Leigh, was commissioned to take a photograph for the cover of the book. The cover image became immediately iconic, with author John Berendt calling it "one of the strongest covers I've ever seen", and the statue became a popular stop for tourists in the area. Eastwood thus chose to use that same powerful image and the film meaningfully ends with a long shot over The bird girl, bearing two identical plates in her hands: they could be used to feed birds but also be considered as the two parts of a balance (Image 4). The feature follows the structure of a real traditional tragedy: the young and beautiful Billy Hanson (Handsford in the book) (Jude Law), a local male prostitute, is fiercely killed during a Christmas party where all Savannah's upper class is reunited in the house of self-made antique dealer Jim Williams (Kevin Spacey). The protagonist, brilliant journalist John Kelso (John Cusack), has been sent from New York to cover the party for the Town and Country local journal, but then finds out he was actually chosen by someone who asked for him to be there. In the little southern town, Kelso immediately discovers a world where magic and public law come together with unnoticed examples of human absurdity (men who walk imaginary dogs, voodoo rituals, old women with charged guns at aristocratic parties, young unmarried women's clubs etc). Among all this bizarre human spectacle and the four times trial which is engaged against Jim, the defendant for premeditated murder, the transgender lady Chablis (Madame DeVeau) is probably the most tragic character: when she takes the floor, the narration is interrupted. Her role could correspond to the one which once belonged to the Greek chorus, who commented with a collective voice on the dramatic action.

It is not a detail, either, if the film starts and ends with approximately the same scene of voodoo priestess Minerva, who is in Roman mythology the goddess of wisdom but also of trade and strategy, the owl of Minerva being also the sacred symbol of wisdom and knowledge and the representation of philosophy, according to Hegel. Her presence is revealing: the spectator can either think that magical, sacred, obscure forces have driven the action or that the whole story is simply the consequence of a tragic, fatal double accident. So in the end, the sudden death of Jim can be seen both as revenge taken by dead Billy to restore justice (which did not happen with the human trial), a curse, or a simple misadventure. To quote one of the most popular sentences from the film: "Truth, like art, is in the eye of the beholder. You believe what you choose and I believe what I know". 


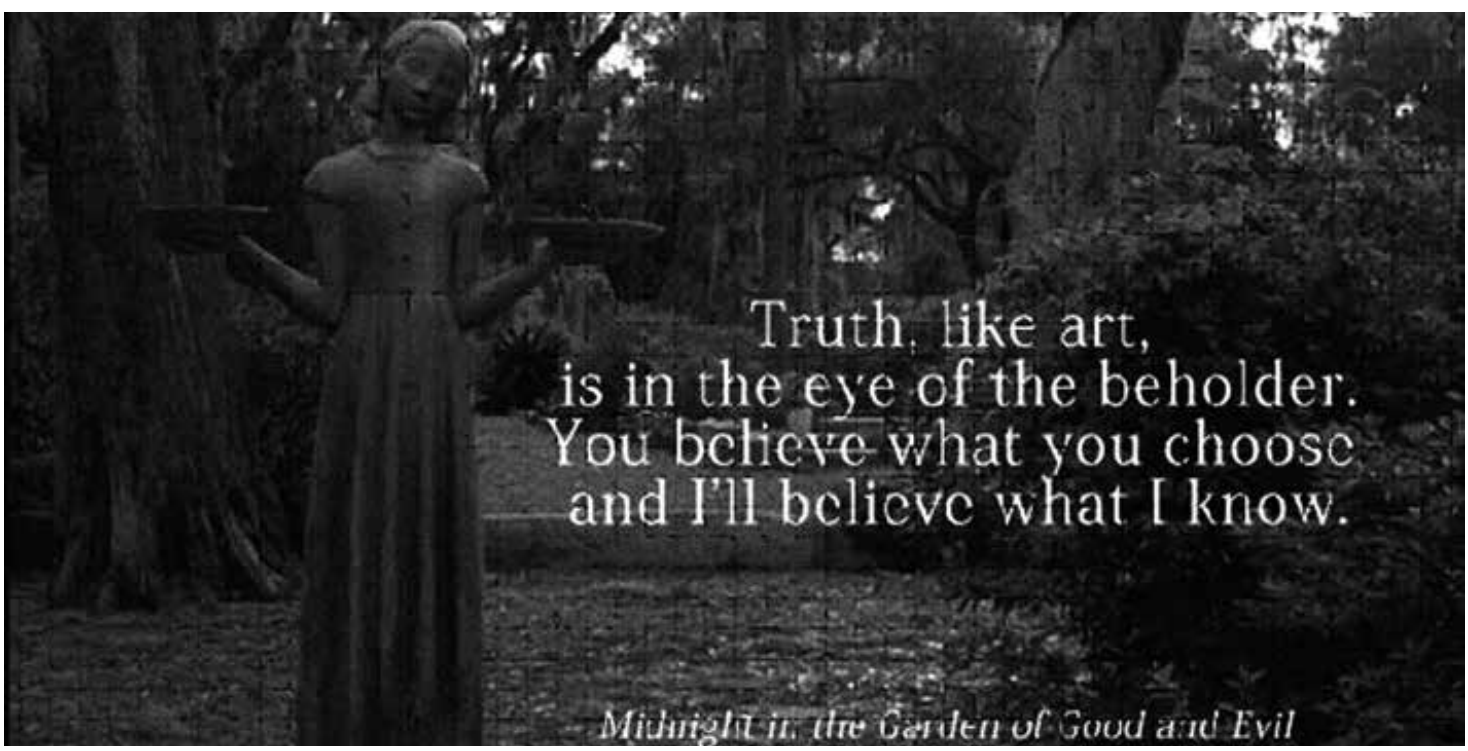

Image 4. Film poster of Midnight in the garden of good and evil (Clint Eastwood, USA, 1997).

\section{In the end, "all is good"}

In the text of a lecture given in Athens in 1955, On the future of tragedy, Camus asserts: "In other words, tragedy is ambiguous, drama is simplistic" (1703). This means that if the forces acting in a drama are either part of what is good or wrong, in the tragedy they belong to the same ambiguous ethical category. Eventually, we could say that those tragic powers do not belong to ethics anymore, they have overcome all the ethical distinctions. Tragic actions are both legitimate and illegitimate, good and bad at the same time. In the tragedy, an ethical revolution intervenes to transform what is considered good, into its opposite. Thus, Camus adds: "Antigone is right, but Creon is not wrong" (1703). Indeed, the two protagonists of Sophocles' play belong to a different religiosity: Antigone's is private and familiar, centred around the home and the cults of dead people. The other, which is represented by the head of the state, Creon, is public and regulated by laws and institutions. Nevertheless, the gods who intervene in the action, Eros and Dionysius, criticise both of them: Creon is accused of being blind and lacking intelligence and interpretation (qualities required from a state leader); Antigone is guilty of having refused Eros in the figure of her fiancé, Haemon. Thus, the dramatic formula "only one is right and justifiable", has to be replaced by the tragic formula "all are justifiable, no one is right" (1703). There is a tragedy where the universal order of things is questioned, perturbed, out-dated and not only peacefully given and accepted (Antigone). And yet, in the excess of doubt and rationalism, tragic spirit is also annihilated. When an absolute dominance of reason occurs, when the only accepted law is human law (Creon), when everything is fully understood, analysed and justified, no tragedy can exist (1705). This is why we must introduce here the concept of tragic fault, without pretending to exhaust its complexity. We could explain it with these words: the tragic fault is irresponsible. Always unknown at the moment when the tragic hero acts, the (fatal) consequences of his action turn out to be irreparable. 
What tragedy assures is to keep alive the mystery about the protagonist's guilt, or, better, the mystery about the total absence of any mystery, and hence of its complete acceptance. The meaning of the tragedy for Camus is retained in the three words pronounced by Oedipus at the very moment he cut his eyes out: "All is good" (1706).

It is for this reason that we return to Camus's pages to affirm that the tragic narrative, in order to be able to still manifest itself in the contemporary era, needs a precarious balance between mystery and reason, human and divine, politics and religion, freedom and the sacred. These are also all the elements we have found in some mainstream features. Exactly as in the Athens of the sixth and fifth centuries $\mathrm{BC}$, where the citizens were divided between a duty to the gods and a democratic ambition, it is that unique and inseparable ambiguity that raises and develops along with the tragic dimension. Its spirit shapes a world divided into opposing forces and where men find themselves acting and at the same time undergoing, where they are both innocent and guilty, seeing and blind, mythical heroes and contemporary citizens. If we consider, according to Camus, the fact that a tragic contemporary epoch is still conceivable (1707) and that tragedy in its structure and spirit is not dead, we must seek a place where this ambiguous balance, like the one carried by The bird girl, a place where this impossible responsibility can still be acted. And this place, for both its massive and political role, would be played by some currents of contemporary cinema.

To conclude, in terms of tragic narrative strategies we should say, again with Camus, that "if everything is a mystery, there is no tragedy. If everything is right either. The tragedy is born between shadow and light, and by their opposition" (1705).

\section{Bibliography:}

Aristotle. La Poétique. In CEuvres. Paris: Gallimard, 2014.

Benjamin, Walter. L'euvre d'art à l'époque de sa reproducibilité technique. Paris: Payot, 2013.

Debord, Guy. La Société du spectacle. Paris: Éditions Buchet-Chastel, 1967.

---. Un art de la guerre. Paris: Bibliothèque Nationale de France - Gallimard, 2013.

Camus, Albert. Sur l'avenir de la tragédie. In Théâtre, récits, nouvelles. Paris: Gallimard, 1962.

Lacan, Jacques. Le séminaire. Livre VII: L'éthique de la psychanalyse 1959-1960. Paris:

Éditions du Seuil, 1986, p. 285-333.

Montani, Pietro (dir.). Hegel, Kierkegaard, Hölderlin, Heidegger, Bultmann. Antigone e la filosofia. Roma: Donzelli Editore, 2001.

Nietzsche. La nascita della tragedia. Bari: Laterza, 2010.

Sichère, Bernard. L'Antigone de Lacan. Conference given on the 02/05/2012. Paris: The French National Library, 2012. Video.

Ungaro, Jean. Américains héros de cinéma. Paris-Budapest-Torino: L’Harmattan, 2005. 
Vernant, Jean-Pierre; Vidal-Naquet, Pierre. Mythe et tragédie en Grèce Ancienne. Paris: Éditions de la découverte, 2000-2001.

Žižek, Slavoj. «Passion du réel, passion du semblant ». ERES, Savoirs et clinique, 2003/2 (n³), p. 39-56. DOI : 10.3917/sc.003.0039. Available online at: https://www.cairn.info/ revue-savoirs-et-cliniques-2003-2-page-39.htm.

\section{Tragic Narrative Strategies in Contemporary American Cinema. Eastwood-Penn-Grey (1995-2001)}

Tragedies were performed for the first time in ancient Greece between the sixth and fifth century BC. A century later, Aristotle in the Poetics gave his famous definition of tragedy, transforming it into a narrative genre. Our aim is primarily to introduce and analyse some characteristics of the tragic scheme. Three main elements will be taken into consideration. We will see that at the very heart of the tragic narration there is "something" unrepresentable, unbearable and nameless that Lacan, in the VII seminar on ethics, names Das Ding or La Chose, The Thing. After that, we will consider the representation of an ethical power which disputes the traditional and institutionalised order. Thirdly, the presence of sacred forces will be evoked to contextualise the ancient and contemporary tragic narrations in a mythical, pre-logical, pre-textual framework. However, in order to identify any forms of tragic narratives in the contemporary era, a consideration of the medium itself cannot be avoided, as tragedies were shown and affected large crowds of people and had a substantial political role. Cinema is thus revealed to be the most privileged media device to present modern tragic narrations and their typical aesthetic solutions. In this article, we will discuss three examples of tragic narratives in mainstream American cinema from the last three decades. Works by Sean Penn (The Pledge, 2001), James Grey (Little Odessa, 1995) and Clint Eastwood (Midnight in the garden of good and evil, 1997) will be investigated.

Keywords: tragic narratives, contemporary American mainstream cinema, aesthetics, psychoanalysis, philosophy of film, narratology. 